\title{
Role of Antioxidant Gene Polymorphisms in Risk and Prognosis of Chronic Myeloid Leukemia
}

\author{
Sailaja Kagita ${ }^{1}$, Raghunadharao Digumarti², Sadhashivudu Gundeti ${ }^{3}$
}

${ }^{1}$ Department of Genetics and Molecular Biology, KIMS-ICON Hospital, Sheelanagar, Visakhapatnam, Andhra Pradesh, India. ${ }^{2}$ Department of Medical Oncology, KIMS-ICON Hospital, Sheelanagar, Visakhapatnam, Andhra Pradesh, India. ${ }^{3}$ Department of Medical Oncology, Nizam's Institute of Medical Sciences, Hyderabad, Telangana, India.

\begin{abstract}
Introduction: We aimed to investigate the possible role of antioxidant enzyme polymorphisms $C A T-21 \mathrm{~A} / \mathrm{T}$ (rs7943316), CAT -262C/T (rs1001179), GPX1 -198C/T (rs1050450), MPO -463G/A (rs2333227), GSTM1 (rs366631) \& GSTT1 (rs17856199) with susceptibility to chronic myeloid leukemia (CML) and their association with tyrosine kinase inhibitor (TKI, imatinib) response. Methods: Six single nucleotide polymorphisms (SNPs) in antioxidant enzyme genes were genotyped in a total of 325 samples, of which 125 were from CML patients and 200 from healthy controls. The SNPs were correlated with various confounding variables lke $B C R-A B L 1$ levels and tyrosine kinase domain mutation status in CML patients. Results: Genotyping results revealed statistically significant associations with $C A T-21 \mathrm{~A} / \mathrm{T}(\mathrm{p}=0.037)$ and $G P X I-198 \mathrm{C} / \mathrm{T}(\mathrm{p}=<0.0001)$ polymorphisms with risk of CML. No associations were observed between CAT -262C/T, MPO -463G/A, GSTM1 \& GSTT1 polymorphisms and CML. The CAT -21A/T polymorphism conferred 2.95 folds increased risk of CML under co-dominant model $(\mathrm{p}=0.024)$ and 2.51 folds risk under dominant models $(\mathrm{p}=0.05)$. In addition, the haplotypes of $C A T$ $-21 \mathrm{~A} / \mathrm{T}$ and $-262 \mathrm{C} / \mathrm{T}$ polymorphisms, ATCC and ATCT conferred higher incidence of CML risk by 2.67 times $(\mathrm{p}=0.05)$ and 2.99 times $(\mathrm{p}=0.045)$. The $G P X 1-198 \mathrm{C} / \mathrm{T}$ polymorphism conferred significantly increased risk of CML under co-dominant model [CC vs CT $(\mathrm{p}=<0.0001)$, CC vs TT $(\mathrm{p}=<0.0001)]$ and dominant models [CC vs $\mathrm{CT}+\mathrm{TT}(\mathrm{p}=<0.0001)]$. The heterozygous GPX1 CT genotype frequency significantly elevated in poor molecular responders $(\mathrm{p}=0.005)$ and TKD mutation carriers $(\mathrm{p}=0.114)$ as compared to respective groups. Conclusions: Our results suggest that the reduced activity of antioxidant enzymes caused by the CAT $-21 \mathrm{~A} / \mathrm{T}$ and $G P X 1-198 \mathrm{C} / \mathrm{T}$ polymorphisms might contribute to increased risk of CML. In addition, the GPXI-198C/T polymorphism was associated with poor molecular response and acquired TKD mutations. Hence, the present study indicates that defective antioxidant defense system might have a strong influence on CML susceptibility and TKI (imatinib) response through oxidative stress.
\end{abstract}

Keywords: Chronic Myeloid leukemia- Imatinib- Resistance- Antioxidant genes- polymorphism

Asian Pac J Cancer Biol, 6 (1), 27-36

\section{Introduction}

Chronic myeloid leukemia (CML) is a hematopoietic stem cell disorder of myeloid precursors, characterized by the presence of Philadelphia $(\mathrm{Ph})$ chromosome, which results from a reciprocal chromosomal translocation $\mathrm{t}(9 ; 22)$, leading to the $B C R-A B L 1$ fusion gene. The $B C R-A B L 1$ gene can modulate DNA repair mechanisms, cell cycle checkpoints, $B c l 2$ proteins and enhances reactive oxygen species (ROS) generation,
Submission Date: 12/21/2020Ａcceptance Date: 02/21/2021

\footnotetext{
Corresponding Author:

Dr. Sailaja Kagita

Department of Genetics and Molecular Biology, KIMS-ICON Hospital, Sheelanagar, Visakhapatnam, Andhra Pradesh, India.

Email: kagitasa@gmail.com
} 
malignancies [6-9]. Antioxidant enzymes such as catalase $(C A T)$, manganese superoxide dismutase $(M n S O D)$, glutathione peroxidase 1 ( GPX1), myeloperoxidase $(M P O)$ and glutathione-S-transferases $(G S T S)$ balance ROS levels and defend cells against oxidative stress. Most of these antioxidant enzymes are highly polymorphic. Genetic variations of these antioxidant enzymes with altered enzymatic activity may contribute to the imbalance of ROS production and scavenging [10-11]. The activity of several antioxidant enzymes was noted to be reduced in CML patients [12]. Several studies demonstrated that polymorphisms in antioxidant enzymes (CAT, MnSOD, GPX1, MPO \& GSTS) might be associated with susceptibility to various solid tumors [13-15] and hematological malignancies [16-20].

Hence, the present study aimed to investigate the possible role of polymorphisms in antioxidant enzyme polymorphisms: Catalase $(C A T)-21 \mathrm{~A} / \mathrm{T} \&$ $-262 \mathrm{C} / \mathrm{T}$, Glutathione peroxidase 1 (GPX1) -198C/ T, Myeloperoxidase (MPO) $-463 \mathrm{G} / \mathrm{A}$, deletion of Glutathione S-Transferase M1 \& T1 (GSTM1 \& GSTT1) with susceptibility to chronic myeloid leukemia and their association with TKI (imatinib) response.

\section{Materials and Methods}

The present study included 325 samples, out of which 125 are from CML patients and 200 were from age \& gender matched controls without a family history of any cancer. The inclusion criteria for patients included $\mathrm{Ph}+$ ve CML cases with confirmed diagnosis, on TKI treatment and TKI refractory cases regardless of age, gender or race. The study was approved by the institutional ethics committee and an informed consent was obtained from patients participating in the study. Blood samples (6mL in EDTA vaccutainer) were collected from both CML patients and controls. Genomic DNA was extracted from blood samples using non-enzymatic rapid salting-out method. The purity \& concentration of DNA samples were checked on Nanodrop1000 and further these DNA samples were subjected for analysis of SNPs in antioxidant enzyme genes.

\section{Genotyping of antioxidant gene SNPS}

Genotyping of CAT -21A/T (rs7943316), CAT -262C/T (rs1001179), GPX1 (-198C/T rs1050450) and MPO (-463G/A rs2333227) was performed by PCR-RFLP (polymerase chain reaction - restriction fragment length polymorphism) method. The null/deletion polymorphism in GSTM1 \& GSTT1 genes (rs366631 \& rs17856199) were performed by multiplex polymerase chain reaction followed by agarose gel electrophoresis. The primers used for amplification and restriction enzymes for RFLP analysis are listed in Table 1. The $C A T(-21 \mathrm{~A} / \mathrm{T} \&-262 \mathrm{C} / \mathrm{T}), G P X 1$ $(-198 \mathrm{C} / \mathrm{T})$ and $M P O(-463 \mathrm{G} / \mathrm{A})$ polymorphism were determined by digesting the PCR amplified products with HinfI, SmaI, ApaI and SsiI restriction enzymes (Table 1).

\section{Statistical analysis}

Chi square and multivariate analysis tests were calculated to test the significance of genotype association with the occurrence of CML and its prognosis. All the $p$ values were two sided and the level of significance was taken as $\mathrm{p}<0.05$. Statistical analyses were performed using the GraphPad Prism software version 6.0 (San Diego, CA) and online VassarStats software. Haplotype and pairwise linkage disequilibrium was calculated using Haploview version 4.2 and cox regression analysis by SPSS version 22 software.

\section{Results}

Baseline characteristics (Table 2)

The demographic and clinical characteristics of CML patients are presented in Table 2. The median age at diagnosis of CML was 42 years (range 12 to 89 years) and a male preponderance was observed with a male to female ratio of 1.6:1. Of the 125 patients, 102 cases presented in chronic phase, 13 in accelerated phase and 10 in blast crisis phase of CML.

Prognostic scores like Sokal, Hasford, and EUTOS (European Treatment Outcome Study) were calculated for all patients using baseline hematological variables [21]. With Sokal risk scoring, $37.6 \%$ of patients had low risk and $62.4 \%$ had intermediate + high risk. With respect to Hasford risk score, $39.2 \%$ had low risk and $60.80 \%$ had intermediate + high risk. When EUTOS risk scores were considered, $72.0 \%$ of patients were presented with low risk and 28\% with high EUTOS risk. Majority of patients were on imatinib (IM) treatment, nearly $42.4 \%$ of patients received higher IM doses $(600 \mathrm{mg} / 800 \mathrm{mg})$, $16.8 \%$ on IM standard dose (400mg), $16.0 \%$ on other drugs $\left(2^{\text {nd }}\right.$ generation TKIs or on clinical trials), $16.8 \%$ deceased and $8 \%$ are newly diagnosed.

Median follow-up of these patients for a period of 40 median months revealed that $20.8 \%$ had optimal response to imatinib and $79.02 \%$ of patients lost respone which might be either due to loss of complete hematological response (CHR), complete cytogenetic response (CCyR), major molecular response (MMR) or presence of TKD mutations.

\section{Correlation with CAT -21A/T polymorphism (Table 3)}

The $C A T-21 \mathrm{~A} / \mathrm{T}$ genotyping results revealed that heterozygous AT genotype frequency was observed to be significantly increased in CML patients compared to controls $(p=0.037)$. This polymorphism was significantly assciated with increased risk of CML. With respect to molecular response, homozygous TT genotype and T allele frequencies were elevated in non-responders i.e., patients having higher $B C R-A B L 1$ expression levels (44.70\%, $0.705)$ compared to responders i.e., patients having lower levels $(35.0 \%, 0.625)(\mathrm{p}=0.259)$. Heterozygous AT genotype frequency was found to be slightly increased in TKD mutation carriers $(p=0.571)$ and in deceased group of patients $(p=0.548)$ when compared to respective groups. No differences were found with either of the prognostic risk scores: Sokal, Hasford or EUTOS.

The $C A T-21 \mathrm{~A} / \mathrm{T}$ polymorphism showed statistically significant association with risk of CML and conferred 
Table 1. Primer Sequences used for Analysis of Polymorphisms in Anti oxidant Enzyme Genes

\begin{tabular}{|c|c|c|c|c|}
\hline Gene & SNP & Primer sequence & Product size & Restriction enzyme \\
\hline \multirow[t]{2}{*}{$C A T$} & $-21 \mathrm{~A} / \mathrm{T}$ & 5'- AATCAGAAGGCAGTCCTCCC-3' & $250 \mathrm{bp}$ & HinfI \\
\hline & (rs7943316) & 5'- TCGGGGAGCACAGAGTGTAC-3' & & \\
\hline \multirow[t]{2}{*}{$C A T$} & $-262 \mathrm{C} / \mathrm{T}$ & 5'- AGAGCCTCGCCCCGCCGGACCG-3' & $185 \mathrm{bp}$ & SmaI \\
\hline & $($ rs1001179) & 5'- TAAGAGCTGAGAAAGCATAGCT-3' & & \\
\hline \multirow[t]{2}{*}{$G P X$} & $-198 \mathrm{C} / \mathrm{T}$ & 5'- TCCAGACCATTGACATCGAG-3' & $222 b p$ & ApaI \\
\hline & $(\mathrm{rs} 1050450)$ & 5'- ACTGGGATCAACAGGACCAG-3' & & \\
\hline \multirow[t]{2}{*}{$M P O$} & $-463 \mathrm{G} / \mathrm{A}$ & 5'- CGGTATAGGCACACAATGGTGAG-3' & $350 \mathrm{bp}$ & SsiI \\
\hline & (rs2333227) & 5'- CAATGGTTCAAGCGATTCTTC-3' & & \\
\hline \multirow[t]{2}{*}{ GSTM1 } & Deletion & 5'- GAACTCCCTGAAAAGCTAAAGC-3' & $219 b p$ & \\
\hline & $(\mathrm{rs} 366631)$ & 5'- GTTGGGCTCAAATATACGGTGG-3' & & \\
\hline \multirow[t]{2}{*}{ GSTT1 } & Deletion & 5'- TTCCTTACTGGTCCTCACATCTC-3' & $480 \mathrm{bp}$ & \\
\hline & (rs17856199) & 5'- TCACCGGATCACGGCCAGCA-3' & & \\
\hline \multirow[t]{2}{*}{ Beta globin } & & 5'- ACACAACTGTGTTCACTAGC-3' & $299 \mathrm{bp}$ & \\
\hline & & 5'- CAACTTCATCCACGTTCACC-3' & & \\
\hline
\end{tabular}

2.95 folds increased risk of CML under codominant (AA vs AT) model (OR=2.953, 95\% CI: 1.206-7.228, $\mathrm{p}=0.024$ ) and 2.51 folds risk under dominant (AA vs $\mathrm{AT}+\mathrm{TT})$ models $(\mathrm{OR}=2.518,95 \% \mathrm{CI}: 1.058-5.992$, $\mathrm{p}=0.05$ ), whereas overdominant model (AT vs AA+TT) was found to be protective against $\mathrm{CML}(\mathrm{OR}=0.632,95 \%$ CI: 0.404-0.994, $\mathrm{p}=0.060$ ) (Table 4).

Correlation with CAT-262C/T polymorphism (Table 5)

There was no significant difference observed between cases and controls $(p=0.711)$, molecular response $(p=0.865)$ and presence or absence of TKD mutations $(\mathrm{p}=0.708)$ with CAT-262C/T polymorphism. This polymorphism was not assciated with risk of CML. Whereas the homozygous CC genotype and $\mathrm{C}$ allele frequencies were found to be elevated in the deceased group $(71.42 \%, 0.857)$ compared to those patients on follow-up $(50.0 \%$; 0.711) ( $\mathrm{p}=0.139)$. The prognostic risk scores were not associated with this polymorphism.

\section{Haplotype analysis of the CAT gene (Table 6)}

The haplotype analysis of the $C A T$ gene polymorphisms $(-21 \mathrm{~A} / \mathrm{T}$ and $-262 \mathrm{C} / \mathrm{T})$ were performed and represented in Table 6. The haplotypes ATCC and ATCT conferred higher incidence of CML risk by 2.67 times $(\mathrm{OR}=2.678$, 95\% CI: 1.051-6.825, $\mathrm{p}=0.05)$ and 2.99 times $(\mathrm{OR}=2.995$, $95 \%$ CI: $1.116-8.037, \mathrm{p}=0.045)$.

Correlation with GPX1 -198C/T polymorphism (Table 7)

The heterozygous CT genotype and $\mathrm{T}$ allele frequencies were significantly increased in CML patients compared to controls $(p=<0.0001)$. With respect to molecular response and TKD mutation status, the heterozygous CT genotype frequency was observed to be significantly elevated in poor molecular responders group (patients having higher $B C R-A B L 1$ levels $)(\mathrm{p}=0.005)$, TKD mutation carriers $(\mathrm{p}=0.114)$ and in patients of advanced phases $(\mathrm{p}=0.292)$ compared to respective groups. With respect to present status, the frequencies of TT genotype and T alleles were found to be slightly increased in deceased group of patients $(23.80 \% ; 0.619)$ compared to those on follow-up $(17.30 \% ; 0.552)(\mathrm{p}=0.404)$. No significant variations were found with prognostic risk scores.

In addition, the GPX1 $-198 \mathrm{C} / \mathrm{T}$ polymorphism increased the risk of CML under codominant model [CC vs $\mathrm{CT}(\mathrm{OR}=7.316,95 \% \mathrm{CI}: 3.198-17.736, \mathrm{p}=<0.0001), \mathrm{CC}$ vs TT $(\mathrm{OR}=9.259,95 \% \mathrm{CI}: 3.489-24.571, \mathrm{p}=<0.0001)]$ and dominant models [CC vs CT+TT $(\mathrm{OR}=7.628,95 \% \mathrm{CI}$ : $3.362-17.310, \mathrm{p}=<0.0001)]$, whereas overdominant model (CT vs CC+TT) was found to be protective against CML $(\mathrm{OR}=0.432,95 \% \mathrm{CI}: 0.262-0.711, \mathrm{p}=0.001)$ (Table 8).

Correlation with MPO-463G/A polymorphism (Table 9) The $M P O-463 \mathrm{G} / \mathrm{A}$ polymorphism demonstrated no significant association between cases and controls $(p=0.494)$, nor with either of the confounding variables like molecular response $(\mathrm{p}=0.465)$, TKD mutation status $(\mathrm{p}=0.392)$, present status $(\mathrm{p}=0.767)$ and prognostic risk scores.

Correlation with GSTM1 \& GSTT1 null/deletion polymorphism (Table 10)

No significant association observed with GSTM1 null polymorphism between cases and controls, molecular response, presence or absence of TKD mutations. Whereas GSTM1 presence genotype (M1) was found to be elevated in deceased group (80.95\%) compared to those on follow-up $(66.34 \%)(\mathrm{p}=0.289)$.

With GSTT1 null polymorphism, the GSTT1 null genotype frequency slightly increased in cases compared to controls $(22.4 \% ; 16.0 \%)(\mathrm{p}=0.193)$. When the results are stratified with confounding variables, the GSTT1 null genotype frequency was found to be higher in non-responders $(27.05 \% ; 12.5 \%)$ and in patients not carrying TKD mutations $(26.31 \% ; 10.0 \%)$ compared to respective groups. There was no difference was observed between follow-up and deceased group of patients with GSTT1 null genotype.

No significant differences were found between GSTM1 \& GSTT1 null/deletion polymorphisms and prognostic 
Table 2. Patient Baseline Characteristics $(n=125)$

\begin{tabular}{|c|c|c|}
\hline & No & $\%$ \\
\hline \multicolumn{3}{|l|}{ Gender } \\
\hline Males & 77 & 61.6 \\
\hline Females & 48 & 38.4 \\
\hline \multicolumn{3}{|l|}{ Age at onset } \\
\hline$\leq 42$ years & 60 & 48 \\
\hline$>42$ years & 65 & 52 \\
\hline \multicolumn{3}{|l|}{ Phase } \\
\hline Chronic & 102 & 81.6 \\
\hline Acute & 23 & 18.4 \\
\hline \multicolumn{3}{|l|}{ Sokal risk } \\
\hline Low & 47 & 37.6 \\
\hline Intermediate & 33 & 26.4 \\
\hline High & 45 & 36 \\
\hline \multicolumn{3}{|l|}{ Hasford risk } \\
\hline Low & 49 & 39.2 \\
\hline Intermediate & 49 & 39.2 \\
\hline High & 27 & 21.6 \\
\hline \multicolumn{3}{|l|}{ EUTOS risk } \\
\hline Low & 90 & 72 \\
\hline High & 35 & 28 \\
\hline \multicolumn{3}{|c|}{$B C R-A B L 1$ levels } \\
\hline$<10 \%$ & 40 & 32 \\
\hline$>10 \%$ & 85 & 68 \\
\hline \multicolumn{3}{|l|}{ TKD mutations } \\
\hline Presence & 30 & 24 \\
\hline Absence & 95 & 76 \\
\hline \multicolumn{3}{|l|}{ Present status } \\
\hline Follow-up & 104 & 83.2 \\
\hline Deceased & 21 & 16.8 \\
\hline
\end{tabular}

risk scores.

Haplotype, Linkage Disequilibrium (LD) and Cox Regression analysis:

The haplotype and pairwise epistasis among six SNPs

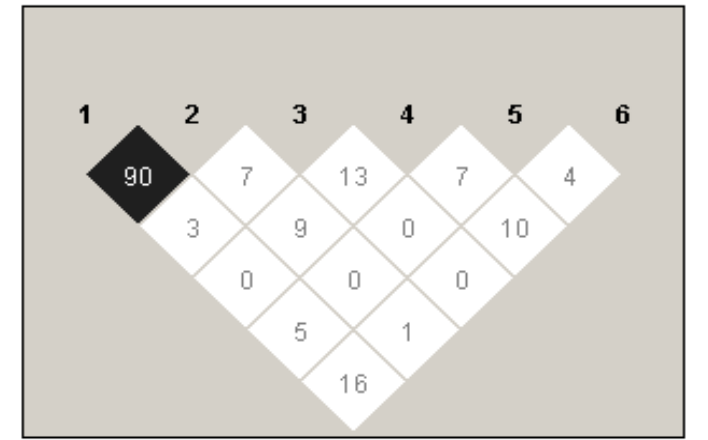

Figure 1. LD plot

did not revealed any significant association, hence data not presented. The linkage disequilibrium (LD) analysis revealed that the two $C A T-21 \mathrm{~A} / \mathrm{T}$ (rs1001179) and $C A T$ -262 C/T (rs7943316) exhibited high LD $\left(D^{\prime}=0.9\right)$. Since the two SNPs are located on chromosome 1, the observed significant LD might be attributed to the physical proximity. None of the other SNP combinations showed significant LD with $\mathrm{D}^{\prime}<0.5$ (Figure 1). Cox regression analysis of SNPs with $B C R-A B L 1$ levels revealed no significant association.

\section{Discussion}

In the present study, we investigated the association of the genetic variations of the antioxidant enzymes: $C A T$ (-21A/T, rs7943316 \& -262C/T, rs1001179), GPX1 (-198C/T, rs1050450), MPO (-463G/A, rs2333227) and GSTM1 (rs366631) \& GSTT1 genes (rs17856199) with susceptibility to CML and their correlation with imatinib (TKI) response.

Our results revealed statistically significant association of $C A T-21 \mathrm{~A} / \mathrm{T}(\mathrm{p}=0.037)$ and $G P X 1-198 \mathrm{C} / \mathrm{T}(\mathrm{p}<0.0001)$ polymorphisms with the risk of CML. No significant associations were observed between $C A T-262 \mathrm{C} / \mathrm{T}$ $(\mathrm{p}=0.711), M P O-463 \mathrm{G} / \mathrm{A}(\mathrm{p}=0.494)$, GSTM1 and GSTT1 null/deletion polymorphisms $(\mathrm{p}=1 ; \mathrm{p}=0.193)$ and CML.

Catalase is an endogenous antioxidant enzyme involved in ROS neutralizing pathways and prevents

Table 3. Genotyping of $C A T-21 \mathrm{~A} / \mathrm{T}$ Polymorphism

\begin{tabular}{|c|c|c|c|c|c|c|c|}
\hline & \multicolumn{2}{|c|}{ Genotype frequency } & \multirow[b]{2}{*}{ TT } & \multirow[b]{2}{*}{ Total } & \multicolumn{2}{|c|}{ Allele frequency } & \multirow[t]{2}{*}{$\mathrm{p}$ value } \\
\hline & AA & AT & & & A & $\mathrm{T}$ & \\
\hline CML cases & $7(5.6 \%)$ & $66(52.8 \%)$ & $52(41.6 \%)$ & 125 & 0.32 & 0.68 & 0.037 \\
\hline Controls & $26(13.0 \%)$ & $83(41.5 \%)$ & $91(45.5 \%)$ & 200 & 0.337 & 0.662 & \\
\hline \multicolumn{8}{|c|}{$B C R-A B L 1$ levels } \\
\hline$<10 \%$ & $4(10.0 \%)$ & $22(55.0 \%)$ & $14(35.0 \%)$ & 40 & 0.375 & 0.625 & 0.259 \\
\hline$>10 \%$ & $3(3.52 \%)$ & $44(51.76 \%)$ & $38(44.70 \%)$ & 85 & 0.294 & 0.705 & \\
\hline \multicolumn{8}{|l|}{ TKD mutations } \\
\hline Presence & $2(6.66 \%)$ & $18(60.0 \%)$ & $10(33.33 \%)$ & 30 & 0.366 & 0.633 & 0.571 \\
\hline Absence & $5(5.26 \%)$ & $48(50.52 \%)$ & $42(44.21 \%)$ & 95 & 0.305 & 0.694 & \\
\hline \multicolumn{8}{|l|}{ Present status } \\
\hline Follow-up & $5(4.80 \%)$ & $54(51.92 \%)$ & $45(43.26 \%)$ & 104 & 0.307 & 0.692 & 0.548 \\
\hline Deceased & $2(9.52 \%)$ & $12(57.14 \%)$ & $7(33.33 \%)$ & 21 & 0.38 & 0.619 & \\
\hline
\end{tabular}


Table 4. Distribution of Odds Ratios between Cases vs Controls with CAT -21A/T Polymorphism

\begin{tabular}{|c|c|c|c|c|}
\hline & CML patients $(n=125)$ & Controls $(n=200)$ & OR $(95 \% \mathrm{CI})$ & $\mathrm{p}$ value \\
\hline \multicolumn{5}{|l|}{ Codominant } \\
\hline AA & $7(5.6 \%)$ & $26(13.0 \%)$ & & \\
\hline $\mathrm{AT}$ & $66(52.8 \%)$ & $83(41.5 \%)$ & $2.953(1.206-7.228)$ & 0.024 \\
\hline TT & $52(41.6 \%)$ & $91(45.5 \%)$ & $2.122(0.861-5.228)$ & 0.145 \\
\hline \multicolumn{5}{|l|}{ Dominant } \\
\hline AA & $7(5.44 \%)$ & $26(13.0 \%)$ & & \\
\hline $\mathrm{AT}+\mathrm{TT}$ & $118(94.55 \%)$ & $174(7.0 \%)$ & $2.518(1.058-5.992)$ & 0.050 \\
\hline \multicolumn{5}{|l|}{ Recessive } \\
\hline $\mathrm{AT}+\mathrm{AA}$ & $73(58.50 \%)$ & $109(54.5 \%)$ & & \\
\hline TT & $52(41.49 \%)$ & $91(45.5 \%)$ & $0.853(0.543-1.340)$ & 0.565 \\
\hline \multicolumn{5}{|c|}{ Overdominant } \\
\hline AT & 66 & 83 & & \\
\hline $\mathrm{AA}+\mathrm{TT}$ & 59 & 117 & $0.632(0.404-0.994)$ & 0.06 \\
\hline
\end{tabular}

Table 5. Genotyping of CAT -262 C/T Polymorphism

\begin{tabular}{|c|c|c|c|c|c|c|c|}
\hline & \multicolumn{3}{|c|}{ Genotype frequency } & & \multicolumn{2}{|c|}{ Allele frequency } & \multirow[t]{2}{*}{$\mathrm{p}$ value } \\
\hline & $\mathrm{CC}$ & $\mathrm{CT}$ & TT & Total & $\mathrm{C}$ & $\mathrm{T}$ & \\
\hline CML cases & $67(53.6 \%)$ & $50(40.0 \%)$ & $8(6.4 \%)$ & 125 & 0.736 & 0.264 & 0.711 \\
\hline Controls & $116(58.0 \%)$ & $71(35.5 \%)$ & $13(6.5 \%)$ & 200 & 0.757 & 0.242 & \\
\hline \multicolumn{8}{|c|}{$B C R-A B L 1$ levels } \\
\hline$<10 \%$ & $21(52.5 \%)$ & $17(42.5 \%)$ & $2(5.0 \%)$ & 40 & 0.737 & 0.262 & 0.865 \\
\hline$>10 \%$ & $46(54.11 \%)$ & $33(38.82 \%)$ & $6(7.05 \%)$ & 85 & 0.735 & 0.264 & \\
\hline \multicolumn{8}{|c|}{ TKD mutations } \\
\hline Presence & $16(53.33 \%)$ & $13(43.33 \%)$ & $1(3.33 \%)$ & 30 & 0.75 & 0.25 & 0.708 \\
\hline Absence & $51(53.68 \%)$ & $37(38.94 \%)$ & $7(7.36 \%)$ & 95 & 0.731 & 0.268 & \\
\hline \multicolumn{8}{|c|}{ Present status } \\
\hline Follow-up & $52(50.0 \%)$ & $44(42.30 \%)$ & $8(7.69 \%)$ & 104 & 0.711 & 0.288 & 0.139 \\
\hline Deceased & $15(71.42 \%)$ & $6(28.57 \%)$ & 0 & 21 & 0.857 & 0.142 & \\
\hline
\end{tabular}

Table 6. Distribution of $C A T(-21 \mathrm{~A} / \mathrm{T}$ and $-262 \mathrm{C} / \mathrm{T})$ Halotypes and their Correlation with Risk of CML

\begin{tabular}{lcccc}
\hline Haplotypes & CML patients $(\mathrm{n}=125)$ & Controls $(\mathrm{n}=200)$ & OR $(95 \% \mathrm{CI})$ & $\mathrm{p}$ value \\
\hline AACC & $7(5.6 \%)$ & $25(12.5 \%)$ & & \\
AACT & 0 & $1(0.5 \%)$ & & 0.05 \\
AATT & 0 & 0 & $2.678(1.051-6.825)$ & 0.045 \\
ATCC & $39(31.2 \%)$ & $52(26.0 \%)$ & $2.995(1.116-8.037)$ & 0.31 \\
ATCT & $26(20.8 \%)$ & $31(15.5 \%)$ & & 0.157 \\
ATTT & $1(0.8 \%)$ & 0 & $1.875(0.696-5.049)$ & 0.475 \\
TTCC & $21(16.8 \%)$ & $30(20.0 \%)$ & $2.556(0.845-6.019)$ & $1.923(0.554-0.298)$ \\
TTCT & $24(19.2 \%)$ & $13(6.5 \%)$ & & \\
TTTT & $7(5.6 \%)$ & & & \\
\hline
\end{tabular}

cellular injury from ROS [22]. Two polymorphisms: $C A T$ $-21 \mathrm{~A} / \mathrm{T}$ with altered gene expression pattern [23] and $C A T-262 \mathrm{C} / \mathrm{T}$ with lower $C A T$ enzyme activity [24] may alter ROS detoxification and increase oxidative stress, implicating oxidative DNA damage and modulating disease risk [25]. In the present study, the $C A T-21 \mathrm{~A} / \mathrm{T}$ polymorphism was significantly associated with increased risk of CML ( $\mathrm{p}=0.037)$.

The stratified genotyping results with various confounding variables revealed that the homozygous variant TT genotype increased in non responders $(p=0.259)$ and the heterozygous AT genotype frequency in TKD mutation carriers $(\mathrm{p}=0.571)$ and in deceased $(\mathrm{p}=0.548)$ group of patients. In addition, the codominant model (AA vs AT) $(\mathrm{p}=0.024)$ and dominant models (combined AT and TT genotypes) $(p=0.05)$ presented significant association with increased risk of CML when compared with AA homozygote. Whereas Liu et al (2016) 
Table 7. Genotyping of GPX1 -198C/T Polymorphism

\begin{tabular}{|c|c|c|c|c|c|c|c|}
\hline & \multicolumn{3}{|c|}{ Genotype frequency } & \multirow[b]{2}{*}{ Total } & \multicolumn{2}{|c|}{ Allele frequency } & \multirow[t]{2}{*}{$\mathrm{p}$ value } \\
\hline & $\mathrm{CC}$ & $\mathrm{CT}$ & $\mathrm{TT}$ & & $\mathrm{C}$ & $\mathrm{T}$ & \\
\hline CML cases & $7(5.6 \%)$ & $95(76.0 \%)$ & $23(18.4 \%)$ & 125 & 0.436 & 0.564 & $<0.0001$ \\
\hline Controls & $62(31.15 \%)$ & $115(57.78 \%)$ & $22(11.05 \%)$ & 199 & 0.6 & 0.399 & \\
\hline \multicolumn{8}{|c|}{$B C R-A B L 1$ levels } \\
\hline$<10 \%$ & $6(15.0 \%)$ & $26(65.0 \%)$ & $8(20.0 \%)$ & 40 & 0.475 & 0.525 & 0.005 \\
\hline$>10 \%$ & $1(1.17 \%)$ & $69(81.17 \%)$ & $15(17.64 \%)$ & 85 & 0.417 & 0.582 & \\
\hline \multicolumn{8}{|c|}{ TKD mutations } \\
\hline Presence & $1(3.33 \%)$ & $27(90.0 \%)$ & $2(6.66 \%)$ & 30 & 0.483 & 0.516 & 0.114 \\
\hline Absence & $6(6.31 \%)$ & $68(71.57 \%)$ & $21(22.10 \%)$ & 95 & 0.421 & 0.578 & \\
\hline \multicolumn{8}{|l|}{ Present status } \\
\hline Follow-up & $7(6.73 \%)$ & $79(75.96 \%)$ & $18(17.30 \%)$ & 104 & 0.447 & 0.552 & 0.404 \\
\hline Deceased & 0 & $16(76.19 \%)$ & $5(23.80 \%)$ & 21 & 0.38 & 0.619 & \\
\hline
\end{tabular}

Table 8. Distribution of Odds Ratios between Cases vs Controls with GPX1-198C/T Polymorphism

\begin{tabular}{lcccc}
\hline & Cases & Controls & OR $(95 \%$ CI $)$ & p value \\
\hline Codominant & & & & \\
CC & $7(5.6 \%)$ & $62(31.15 \%)$ & & $<0.0001$ \\
CT & $95(76.0 \%)$ & $115(57.78 \%)$ & $7.316(3.198-17.736)$ & $<0.0001$ \\
TT & $23(18.4 \%)$ & $22(11.05 \%)$ & $9.259(3.489-24.571)$ & $<0.0001$ \\
Dominant & & & & 0.089 \\
CC & $7(55.10 \%)$ & $62(58.0 \%)$ & $7.628(3.362-17.310)$ & \\
CT+TT & $118(44.89 \%)$ & $137(42.0 \%)$ & & $1.814(0.963-3.417)$ \\
Recessive & & & & \\
CT+CC & $102(93.87 \%)$ & $177(93.5 \%)$ & & \\
TT & $23(6.12 \%)$ & $22(6.5 \%)$ & & \\
Overdominant & & 115 & & \\
CT & 95 & 84 & & \\
CC+TT & 30 & & & \\
\hline
\end{tabular}

Table 9. Genotyping of MPO-G463A Polymorphism

\begin{tabular}{|c|c|c|c|c|c|c|c|}
\hline & \multicolumn{3}{|c|}{ Genotype frequency } & \multicolumn{3}{|c|}{ Allele frequency } & \multirow[t]{2}{*}{$\mathrm{p}$ value } \\
\hline & GG & GA & AA & Total & G & A & \\
\hline CML cases & $90(72.0 \%)$ & $33(26.4 \%)$ & $2(1.6 \%)$ & 125 & 0.852 & 0.148 & 0.494 \\
\hline Controls & $135(67.5 \%)$ & $58(29.0 \%)$ & $7(3.5 \%)$ & 200 & 0.82 & 0.18 & \\
\hline \multicolumn{8}{|c|}{$B C R-A B L 1$ levels } \\
\hline$<10 \%$ & $26(65.0 \%)$ & $13(32.5 \%)$ & $1(2.5 \%)$ & 40 & 0.812 & 0.187 & 0.465 \\
\hline$>10 \%$ & $64(75.29 \%)$ & $20(23.52 \%)$ & $1(1.17 \%)$ & 85 & 0.87 & 0.129 & \\
\hline \multicolumn{8}{|l|}{ TKD mutations } \\
\hline Presence & $19(63.33 \%)$ & $10(33.33 \%)$ & $1(3.33 \%)$ & 30 & 0.8 & 0.2 & 0.392 \\
\hline Absence & $71(74.73 \%)$ & $23(24.21 \%)$ & $1(1.05 \%)$ & 95 & 0.868 & 0.131 & \\
\hline \multicolumn{8}{|l|}{ Present status } \\
\hline Follow-up & $74(71.15 \%)$ & $28(26.92 \%)$ & $2(1.92 \%)$ & 104 & 0.846 & 0.153 & 0.767 \\
\hline Deceased & $16(76.15 \%)$ & $5(23.80 \%)$ & 0 & 21 & 0.88 & 0.119 & \\
\hline
\end{tabular}

reported an increased cancer risk with recessive model and homozygote model [26]. This indicates that variant $\mathrm{T}$ allele with lower catalase activity and thus increased levels of ROS may contribute to genomic instability and increased risk of cancer. Earlier studies reported no significant associations with the risk of colorectal cancer
[27], gastric cancer (GC) and hepatocellular carcinoma (HCC) [13].

In our study, we found no evidence of the CAT -262 $\mathrm{C} / \mathrm{T}$ polymorphism with CML risk or its association with confounding variables. Our results are in accordance with earlier studies that reported no significant association with 
Table 10. Genotyping of GSTM1 \& GSTT1 Deletion Polymorphism

\begin{tabular}{|c|c|c|c|c|c|c|c|}
\hline \multicolumn{8}{|c|}{ Genotype frequencies } \\
\hline & $\mathrm{T} 1$ & T0 & $\mathrm{p}$ value & M1 & M0 & $\mathrm{p}$ value & Total \\
\hline CML cases & $97(77.6 \%)$ & $28(22.4 \%)$ & 0.193 & $86(68.8 \%)$ & $39(31.2 \%)$ & 1 & 125 \\
\hline Controls & $168(84.0 \%)$ & $32(16.0 \%)$ & & $136(68.0 \%)$ & $64(32.0 \%)$ & & 200 \\
\hline \multicolumn{8}{|c|}{$B C R-A B L 1$ levels } \\
\hline$<10 \%$ & $35(87.5 \%)$ & $5(12.5 \%)$ & 0.111 & $27(67.5 \%)$ & $13(32.5 \%)$ & 1 & 40 \\
\hline$>10 \%$ & $62(72.94 \%)$ & $23(27.05 \%)$ & & $59(69.41 \%)$ & $26(30.58 \%)$ & & 85 \\
\hline \multicolumn{8}{|c|}{ TKD mutations } \\
\hline Presence & $27(90.0 \%)$ & $3(10.0 \%)$ & 0.105 & $22(73.33 \%)$ & $8(26.66 \%)$ & 0.698 & 30 \\
\hline Absence & $70(73.68 \%)$ & $25(26.31 \%)$ & & $64(67.36 \%)$ & $31(32.63 \%)$ & & 95 \\
\hline \multicolumn{8}{|c|}{ Present status } \\
\hline Follow-up & $80(76.92 \%)$ & $24(23.07 \%)$ & 0.92 & $69(66.34 \%)$ & $35(33.65 \%)$ & 0.289 & 104 \\
\hline Deceased & $17(80.95 \%)$ & $4(19.04 \%)$ & & $17(80.95 \%)$ & $4(19.04 \%)$ & & 21 \\
\hline
\end{tabular}

risk of hepatocellular carcinoma [28], breast cancer [29], and gastric cancer [30]. Previous other studies showed significant increased risk of cervical cancer [15], breast cancer [31], hepatocellular carcinoma [32] and prostate cancer [33]. Whereas others reported that $-262 \mathrm{C} / \mathrm{T}$ polymorphism was a protective factor with respect to chronic myeloid leukemia [19] and hepatocellular carcinoma susceptibility [14-17].

$G P X 1$ is a key enzyme of the antioxidative system that detoxifies peroxide radicals and lipid hydroperoxides. The $-198 \mathrm{C} / \mathrm{T}$ (Pro200Leu) polymorphism in GPX1 is associated with reduced enzyme activity [34-35]. Previous studies reported that higher GPX1 activity is required to counterbalance the ROS levels and related damage occurring during initiation or progression of the cancer [36-39]. We obseved statistically significant association of the homozygous variant TT genotype with CML risk $(\mathrm{p}=<0.0001)$. The stratified results of confounding variables presented the significant association of GPX1 $-198 \mathrm{C} / \mathrm{T}$ polymorphism with poor molecular response $(p=0.005)$ and acquired TKD mutations $(p=0.114)$. In addition, the codominant (CC vs $\mathrm{CT}$ and $\mathrm{CC}$ vs TT) and dominant (CC vs CT+TT) models conferred increased risk of $\mathrm{CML}$ when compared with $\mathrm{CC}$ homozygote $(p=<0.0001)$. Our results were in accordance with others findings on breast cancer [39-41], bladder cancer [42] and lung cancer [43]. This indicates that the variant Leu allele with reduced enzyme activity might increase ROS levels thereby induced oxidative DNA damage and increased susceptibility to cancer. Whereas other studies failed to find an association of GPX1-198C/T polymorphism with the risk of CML [19], breast cancer [44-45] and prostate cancer [46].

Glutathione S-transferases (GSTs) are involved in detoxification of a wide range of carcinogens and ROS thereby offering protection against oxidative DNA damage. GST enzymes are polymorphic, which may contribute to the inter-individual variability in the response to oxidative stress suggesting its role in carcinogenesis and risk for cancer. In the present study, the GSTM1 and GSTT1 null/deletion polymorphisms were not associated with risk of CML. Our results are similar with earlier studies on CML [20]. Previous studies on the GSTT1 null polymorphism reported positive association with risk of CML [47-50] and AML [20]. Earlier studies on GSTM1 null polymorphism showed no association the risk of CML [50], AML [51] and breast cancer [52].

Myeloperoxidase $(M P O)$ is an endogenous oxidant enzyme that activates carcinogens [53]. A single nucleotide polymorphism in the promoter region of the MPO gene, G-463A (rs2333227) has been associated with reduced mRNA expression and transcriptional activity and subsequent decreased metabolic activation of procarcinogens [54]. In the present study, no evidence of $M P O-463 \mathrm{G} / \mathrm{A}$ polymorphism with the risk of CML was observed. Our results were in accordance with earlier studies on ALL [55], AML [56] and breast cancer [57]. Whereas others reported that the A allele with reduced $M P O$ activity and ROS production has been associated with decreased risk of breast cancer [58], lung cancer [59] and prostate cancer [60].

In conclusion, our results suggest that the reduced activity of antioxidant enzymes caused by the $C A T-21 \mathrm{~A} / \mathrm{T}$ and $G P X 1-198 \mathrm{C} / \mathrm{T}$ polymorphisms might contribute to increased risk of CML. In addition, the GPX1-198C/T polymorphism was associated with poor molecular response and acquired TKD mutations. Hence, the present study indicates that defective antioxidant defense system might have a strong influence on CML susceptibility and TKI (imatinib) response through oxidative stress.

\section{Acknowledgments}

The authors would be grateful to the participants.

\section{Financial support}

This work was partially supported through a grant by Science and Engineering Research Board (SERB), Startup Research Grant for young Scientists, Government of India (Dr. Sailaja Kagita).

\section{Conflicts of interest}

There are no conflicts of interest. 


\section{References}

1. Sattler M, Verma S, Shrikhande G, Byrne CH, Pride YB, Winkler T, Greenfield EA, Salgia R, Griffin JD. The BCR/ ABL Tyrosine Kinase Induces Production of Reactive Oxygen Species in Hematopoietic Cells. Journal of Biological Chemistry. 2000 08;275(32):24273-24278. https://doi.org/10.1074/jbc.m002094200

2. Nieborowska-Skorska M, Flis S, Skorski T. AKT-induced reactive oxygen species generate imatinib-resistant clones emerging from chronic myeloid leukemia progenitor cells. Leukemia. 201408 25;28(12):2416-2418. https://doi. org/10.1038/leu.2014.249

3. Slupianek A, Falinski R, Znojek P, Stoklosa T, Flis S, Doneddu V, Pytel D, Synowiec E, Blasiak J, Bellacosa A, Skorski T. $B C R-A B L 1$ kinase inhibits uracil DNA glycosylase UNG2 to enhance oxidative DNA damage and stimulate genomic instability. Leukemia. 2012 Oct 09;27(3):629-634. https:// doi.org/10.1038/leu.2012.294

4. Kuo MT. Redox Regulation of Multidrug Resistance in Cancer Chemotherapy: Molecular Mechanisms and Therapeutic Opportunities. Antioxidants \& Redox Signaling. 2009 01;11(1):99-133. https://doi.org/10.1089/ars.2008.2095

5. Galadari S, Rahman A, Pallichankandy S, Thayyullathil F. Reactive oxygen species and cancer paradox: To promote or to suppress?. Free Radical Biology and Medicine. 2017 03;104:144-164. https://doi.org/10.1016/j. freeradbiomed.2017.01.004

6. Chan DW, Liu VW, Tsao GS, Yao K, Furukawa T, Chan KK, Ngan HY. Loss of MKP3 mediated by oxidative stress enhances tumorigenicity and chemoresistance of ovarian cancer cells. Carcinogenesis. 200806 16;29(9):1742-1750. https://doi.org/10.1093/carcin/bgn167

7. Liu L, Hu X, Xia C, He J, Zhou Q, Shi X, Fang J, Jiang B. Reactive oxygen species regulate epidermal growth factorinduced vascular endothelial growth factor and hypoxiainducible factor- $1 \alpha$ expression through activation of AKT and P70S6K1 in human ovarian cancer cells. Free Radical Biology and Medicine. 2006 Nov;41(10):1521-1533. https:// doi.org/10.1016/j.freeradbiomed.2006.08.003

8. Marinho HS, Real C, Cyrne L, Soares H, Antunes F. Hydrogen peroxide sensing, signaling and regulation of transcription factors. Redox Biology. 2014;2:535-562. https://doi. org/10.1016/j.redox.2014.02.006

9. Udensi UK, Tchounwou PB. Dual effect of oxidative stress on leukemia cancer induction and treatment. Journal of Experimental \& Clinical Cancer Research. 2014 Dec;33(1). https://doi.org/10.1186/s13046-014-0106-5

10. Röhrdanz E, Kahl R. Alterations of Antioxidant Enzyme Expression in Response to Hydrogen Peroxide. Free Radical Biology and Medicine. 1998 01;24(1):27-38. https://doi. org/10.1016/s0891-5849(97)00159-7

11. Shinde A, Ganu J, Naik P. Effect of Free Radicals \& Antioxidants on Oxidative Stress: A Review. Journal of Dental and Allied Sciences. 2012;1(2):63. https://doi. org/10.4103/2277-4696.159144

12. Kumerova A, Lece A, Skesters A, Silova A, Petuhovs V. Anemia and antioxidant defence of the red blood cells. Mater Med Pol. 1998;30(1-2):12-5.

13. Lee JH, Park RY, Lee CS, Jeoung EJ, Nam SY, Lee JG, Han KY, Lee HJ, Chung JH, Ahn YG, Yim SV, Cho JY, Park YH. No Association between Catalase Gene Polymorphism and Gastric Carcinoma and Hepatocellular Carcinoma in Koreans. Cancer Research and Treatment. 2002 Dec 31;34(6):432-435. https://doi.org/10.4143/crt.2002.34.6.432

14. Nahon P, Sutton A, Rufat P, Charnaux N, Mansouri A,
Moreau R, Ganne-Carrié N, Grando-Lemaire V, N'Kontchou G, Trinchet J, Pessayre D, Beaugrand M. A variant in myeloperoxidase promoter hastens the emergence of hepatocellular carcinoma in patients with HCV-related cirrhosis. Journal of Hepatology. 2012 02;56(2):426-432. https://doi.org/10.1016/j.jhep.2011.08.010

15. Castaldo SA, da Silva AP, Matos A, Inácio Â, Bicho M, Medeiros R, Alho I, Bicho MC. The role of CYBA (p22phox) and catalase genetic polymorphisms and their possible epistatic interaction in cervical cancer. Tumor Biology. 2014 Oct 12;36(2):909-914. https://doi.org/10.1007/s13277014-2714-2

16. Zhou F, Pan Y, Wei Y, Zhang R, Bai G, Shen Q, Meng S, Le X, Andreeff M, Claret FX. Jab1/Csn5-Thioredoxin Signaling in Relapsed Acute Monocytic Leukemia under Oxidative Stress. Clinical Cancer Research. 201703 07;23(15):44504461. https://doi.org/10.1158/1078-0432.ccr-16-2426

17. Su S, He K, Li J, Wu J, Zhang M, Feng C, Xia X, Li B. Genetic polymorphisms in antioxidant enzyme genes and susceptibility to hepatocellular carcinoma in Chinese population: a case-control study. Tumor Biology. 201504 19;36(6):4627-4632. https://doi.org/10.1007/s13277-0153110-2

18. Moulik NR, Parveen F, Kumar A, Agrawal S. GlutathioneS-transferase polymorphism and acute lymphoblastic leukemia (ALL) in north Indian children: a case-control study and meta-analysis. Journal of Human Genetics. 2014 08 07;59(9):529-535. https://doi.org/10.1038/jhg.2014.66

19. Bănescu C, Trifa AP, Voidăzan S, Moldovan VG, Macarie I, Benedek Lazar E, Dima D, Duicu C, Dobreanu M. CAT, GPX1, MnSOD, GSTM1, GSTT1, andGSTP1Genetic Polymorphisms in Chronic Myeloid Leukemia: A CaseControl Study. Oxidative Medicine and Cellular Longevity. 2014;2014:1-6. https://doi.org/10.1155/2014/875861

20. Löffler H, Bergmann J, Hochhaus A, Hehlmann R, Krämer A. Reduced risk for chronic myelogenous leukemia in individuals with the cytochrome P-450 gene polymorphism CYP1A1*2A. Blood. 2001 Dec 15;98(13):3874-3875. https://doi.org/10.1182/blood.v98.13.3874

21. Baccarani. Calculation of Relative Risk of CML Patients. European LeukemiaNet (ELN) 2006. https://www.leukemianet.org/content/leukemias/cml/euro_and_sokal_score/ index_eng.html..

22. Góth L, Rass P, Páy A. Catalase enzyme mutations and their association with diseases. Molecular Diagnosis. 2004 09;8(3):141-149. https://doi.org/10.1007/bf03260057

23. Ahn J. Associations between Catalase Phenotype and Genotype: Modification by Epidemiologic Factors. Cancer Epidemiology Biomarkers \& Prevention. 200606 01;15(6):1217-1222. https://doi.org/10.1158/1055-9965. epi-06-0104

24. Panduru N, Mota E, Mota M. Polymorphism of catalase gene promoter in Romanian patients with diabetic kidney disease and type 1 diabetes. Rom J Intern Med. 2010;48:81-8.

25. Forsberg L, Lyrenäs L, Morgenstern R, de Faire U. A common functional C-T substitution polymorphism in the promoter region of the human catalase gene influences transcription factor binding, reporter gene transcription and is correlated to blood catalase levels. Free Radical Biology and Medicine. 2001 03;30(5):500-505. https://doi. org/10.1016/s0891-5849(00)00487-1

26. Liu K, Liu X, Wang M, Wang X, Kang H, Lin S, Yang P, Dai C, Xu P, Li S, Dai Z. Two common functional catalase gene polymorphisms (rs1001179 and rs794316) and cancer susceptibility: evidence from 14,942 cancer cases and 43,285 controls. Oncotarget. 201607 15;7(39):62954-62965. https:// doi.org/10.18632/oncotarget.10617 
27. Chang D, Hu Z, Zhang L. Association of Catalase Genotype with Oxidative Stress in the Predication of Colorectal Cancer modification by epidemiological factors. Biomed Environ Sci. 2012;25(2):156-62. https://doi.org/10.3967/08953988.2012.02.005

28. Liu Y, Xie L, Zhao J, Huang X, Song L, Luo J, Ma L, Li S, Qin X. Association Between Catalase Gene Polymorphisms and Risk of Chronic Hepatitis B, Hepatitis B Virus-Related Liver Cirrhosis and Hepatocellular Carcinoma in Guangxi Population. Medicine. 2015 04;94(13):e702. https://doi. org $/ 10.1097 / \mathrm{md} .0000000000000702$

29. Saadat M, Saadat S. Genetic Polymorphism of CAT C-262 $\mathrm{T}$ and Susceptibility to Breast Cancer, a Case-Control Study and Meta-Analysis of the Literatures. Pathology \& Oncology Research. 2014 09 25;21(2):433-437. https://doi. org/10.1007/s12253-014-9840-4

30. Ebrahimpour S, Saadat I. Association of CAT C-262T and SOD1 A251G single nucleotide polymorphisms susceptible to gastric cancer. Mol Biol Res Commun. 2014;3(4):223-9.

31. Ahn J, Gammon MD, Santella RM, Gaudet MM, Britton JA, Teitelbaum SL, Terry MB, Nowell S, Davis W, Garza C, Neugut AI, Ambrosone CB. Associations between Breast Cancer Risk and the Catalase Genotype, Fruit and Vegetable Consumption, and Supplement Use. American Journal of Epidemiology. 200509 28;162(10):943-952. https://doi. org/10.1093/aje/kwi306

32. Ezzikouri S, Feydi AEE, Afifi R, Benazzouz M, Hassar M, Pineau P, Benjelloun S. Polymorphisms in antioxidant defence genes and susceptibility to hepatocellular carcinoma in a Moroccan population. Free Radical Research. 2009 Nov 23;44(2):208-216. https://doi. org/10.3109/10715760903402906

33. Geybels MS, van den Brandt PA, van Schooten FJ, Verhage BA. Oxidative Stress-Related Genetic Variants, Pro- and Antioxidant Intake and Status, and Advanced Prostate Cancer Risk. Cancer Epidemiology Biomarkers \& Prevention. 2014 Oct 14;24(1):178-186. https://doi. org/10.1158/1055-9965.epi-14-0968

34. Forsberg L, de Faire U, Marklund SL, Andersson PM, Stegmayr B, Morgenstern R. Phenotype Determination of a Common Pro-Leu Polymorphism in Human Glutathione Peroxidase 1. Blood Cells, Molecules, and Diseases. 2000 Oct;26(5):423-426. https://doi.org/10.1006/bcmd.2000.0325

35. Hu Y, Diamond A. Role of glutathione peroxidase 1 in breast cancer. loss of heterozygosity and allelic differences in the response to selenium. Cancer Res. 2003;63:3347-51.

36. Liwei L, Wei Z, Ruifa H, Chunyu L. Association between genetic variants in glutathione peroxidase 1 gene and risk of prostate cancer: a meta-analysis. Molecular Biology Reports. 201206 15;39(9):8615-8619. https://doi.org/10.1007/ s11033-012-1715-8

37. Hu J, Zhou G, Wang N, Wang Y. GPX1 Pro198Leu polymorphism and breast cancer risk: a meta-analysis. Breast Cancer Research and Treatment. 201003 21;124(2):425-431. https://doi.org/10.1007/s10549-010-0841-z

38. Chen J, Cao Q, Qin C, Shao P, Wu Y, Wang M, Zhang Z, Yin C. GPx-1 polymorphism (rs1050450) contributes to tumor susceptibility: evidence from meta-analysis. Journal of Cancer Research and Clinical Oncology. 2011 08 13;137(10):1553-1561. https://doi.org/10.1007/s00432011-1033-x

39. Méplan C, Dragsted LO, Ravn-Haren G, Tjønneland A, Vogel U, Hesketh J. Association between Polymorphisms in Glutathione Peroxidase and Selenoprotein P Genes, Glutathione Peroxidase Activity, HRT Use and Breast Cancer Risk. Coleman WB. PLoS ONE. 201309 10;8(9):e73316. https://doi.org/10.1371/journal.pone.0073316
40. Ravn-Haren G, Olsen A, Tjønneland A, Dragsted LO, Nexø BA, Wallin H, Overvad K, Raaschou-Nielsen O, Vogel U. Associations between GPX1 Pro198Leu polymorphism, erythrocyte GPX activity, alcohol consumption and breast cancer risk in a prospective cohort study. Carcinogenesis. 2005 Nov 14;27(4):820-825. https://doi.org/10.1093/carcin/ bgi2 267

41. Jablonska E, Gromadzinska J, Peplonska B, Fendler W, Reszka E, Krol MB, Wieczorek E, Bukowska A, Gresner P, Galicki M, Zambrano Quispe O, Morawiec Z, Wasowicz W. Lipid peroxidation and glutathione peroxidase activity relationship in breast cancer depends on functional polymorphism of GPX1. BMC Cancer. 2015 Oct 07;15(1). https://doi.org/10.1186/s12885-015-1680-4

42. Paz-y-Mino MJ, Munoz A, Lopez-Cortes. Frequency of polymorphisms pro198leu in GPX-1 gene and ile58thr in MnSOD gene in the altitude Ecuadorian population with bladder cancer. Oncology Research. 2010;18(8):395-400.

43. Ratnasinghe D, Tangrea J, Andersen M, Barrett M, Virtamo J, et al. Glutathione peroxidase codon 198 polymorphism variant increases lung cancer risk. Cancer Res. 2000;60(22):6381-3.

44. Knight JA. Genetic Variants of GPX1 and SOD2 and Breast Cancer Risk at the Ontario Site of the Breast Cancer Family Registry. Cancer Epidemiology Biomarkers \& Prevention. 200401 01;13(1):146-149. https://doi.org/10.1158/10559965.epi-03-0164

45. Cox D, Hankinson S, Kraft P, Hunter D. No association between GPX1 Pro198Leu and breast cancer risk. Cancer Epidemiol Biomarkers Prev. 2004;13:1821-2.

46. Geybels MS, van den Brandt PA, Schouten LJ, van Schooten FJ, van Breda SG, Rayman MP, Green FR, Verhage BAJ. Selenoprotein Gene Variants, Toenail Selenium Levels, and Risk for Advanced Prostate Cancer. JNCI: Journal of the National Cancer Institute. 201402 22;106(3). https://doi. org/10.1093/jnci/dju003

47. Taspinar M, Aydos S, Comez O, Elhan A, Karabulut H, et al. CYP1A1, GST gene polymorphisms and risk of chronic myeloid leukemia. Swiss Med Wkly. 2008;138(1-2):12-7.

48. Özten N, Sunguroğlu A, Bosland MC. Variations in glutathione-S-transferase genes influence risk of chronic myeloid leukemia. Hematological Oncology. 2011 Oct 04;30(3):150-155. https://doi.org/10.1002/hon.1018

49. Bhat G, Bhat A, Wani A, Sadiq N, Jeelani S, Kaur R, Masood A, Ganai B. Polymorphic Variation in Glutathione-Stransferase Genes and Risk of Chronic Myeloid Leukaemia in the Kashmiri Population. Asian Pacific Journal of Cancer Prevention. 201201 31;13(1):69-73. https://doi.org/10.7314/ apjcp.2012.13.1.069

50. He H, Zhang X, Sun J, Hu S, Ma Y, Dong Y, Lu J. Glutathione S-transferase gene polymorphisms and susceptibility to chronic myeloid leukemia. Tumor Biology. 201403 23;35(6):6119-6125. https://doi.org/10.1007/s13277-014$1810-7$

51. Zhou L, Zhu Y, Zhang X, Li Y, Liu Z. Risk Effects of GST Gene Polymorphisms in Patients with Acute Myeloid Leukemia: A Prospective Study. Asian Pacific Journal of Cancer Prevention. 201306 30;14(6):3861-3864. https:// doi.org/10.7314/apjcp.2013.14.6.3861

52. Bailey L, Roodi N, Verrier C, Yee C, Dupont W, et al. Breast cancer and CYP1A1, GSTM1, and GSTT1 polymorphisms, evidence of a lack of association in Caucasians and African Americans. Cancer Res. 1998;58:65-70.. 1998;58:65-70.

53. Petruska JM, Mosebrook D, Jakab GJ, Trush MA. Myeloperoxidase-enhanced formation of $( \pm)$-trans-7,8dihydroxy-7,8-dihydrobenzo[a] pyrene adducts in lung tissue in vitro: a role of pulmonary inflammation in the bioactivation 
of a procarcinogen. Carcinogenesis. 1992;13(7):1075-1081. https://doi.org/10.1093/carcin/13.7.1075

54. Hansson M, Olsson I, Nauseef WM. Biosynthesis, processing, and sorting of human myeloperoxidase. Archives of Biochemistry and Biophysics. 2006 01;445(2):214-224. https://doi.org/10.1016/j.abb.2005.08.009

55. Krajinovic M, Sinnett H, Richer C, Labuda D, Sinnett D. Role ofNQO1,MPO andCYP2E1 genetic polymorphisms in the susceptibility to childhood acute lymphoblastic leukemia. International Journal of Cancer. 2001 Dec 27;97(2):230-236. https://doi.org/10.1002/ijc.1589

56. Morgan GJ, Smith MT. Metabolic Enzyme Polymorphisms and Susceptibility to Acute Leukemia in Adults. American Journal of PharmacoGenomics. 2002;2(2):79-92. https://doi. org/10.2165/00129785-200202020-00002

57. Yang J, Ambrosone CB, Hong C, Ahn J, Rodriguez C, Thun MJ, Calle EE. Relationships between polymorphisms in NOS3 and MPO genes, cigarette smoking and risk of post-menopausal breast cancer. Carcinogenesis. 200701 18;28(6):1247-1253. https://doi.org/10.1093/carcin/bgm016

58. Lin S, Chou Y, Wu M, Wu C, Lin W, Yu C, Yu J, You S, Chen C, Sun C. Genetic variants of myeloperoxidase and catechol-O-methyltransferase and breast cancer risk. European Journal of Cancer Prevention. 2005 06;14(3):257261. https://doi.org/10.1097/00008469-200506000-00010

59. Feyler A, Voho A, Bouchardy C. Point myeloperoxidase $-463 \mathrm{G} \rightarrow \mathrm{A}$ polymorphism and lung cancer risk. Cancer Epidemiol Biomarkers. 2002;11:1550-4.

60. Choi J, Neuhouser ML, Barnett MJ, Hong C, Kristal AR, Thornquist MD, King IB, Goodman GE, Ambrosone CB. Iron intake, oxidative stress-related genes ( MnSOD and $M P O$ ) and prostate cancer risk in CARET cohort. Carcinogenesis. 200802 22;29(5):964-970. https://doi. org/10.1093/carcin/bgn056

\section{(c) (i) (3)}

This work is licensed under a Creative Commons AttributionNon Commercial 4.0 International License. 